\title{
PENGARUH PERSENTASE PENCAMPURAN AIR DALAM RANSUM TERHADAP PERFORMA ITIK PEKING JANTAN PADA PERIODE STARTER
}

\author{
Khalidin \\ Prodi Peternakan Fakultas Pertanian \\ Universitas Jabal Ghafur Sigli
}

\begin{abstract}
Abstrak: Penelitian ini bertujuan untuk Penelitian ini bertujuan untuk mengetahui performa itik peking jantan pada fase starter yang diberikan pakan dengan persentase pertambahan jumlah air yang berbeda. Metode yang digunakan adalah percobaan lapangan yang disusun dengan menggunakan rancangan acak lengkap (RAL) yang terdiri dari empat perlakuan dengan lima ulangan. Masing-masing perlakuan tersebut adalah $P_{0}$ (ransum komersial $511+0 \%$ air sebagai kontrol), $P_{1}$ (ransum komersial $511+10 \%$ air $), P_{2}$ (ransum komersial $511+20 \%$ air $)$ dan $P_{3}$ (ransum komersial $511+30 \%$ air). Anak itik peking jatan yang digunakan adalah berumur satu minggu sebanyak 60 ekor. Data yang diamati adalah konsumsi ransum, pertambahan bobot badan dan konversi ransum. Hasil penelitian menunjukkanbahwa persentase penambahan jumlah air dalam ransum komersial berpengaruh sangat nyata terhadap konsumsi ransum dan konversi ransum itik peking jantan pada preriode starter namun tidak berpengarh nyata terhadap pertambahan bobot badan.Perlakuan penambahan air sebesar $30 \%$ dari berat ransum menghasilkan konsumsi ransum dan konversi ransum terendah sedangkan konsumsi ransum dan konversi ransum tertinggi dengan perlakuan tanpa penambahan air, antar semиa perlakuan berbeda sangat nyata.
\end{abstract}

Kata kunci: ransum, performa, itik peking dan starter.

\section{PENDAHULUAN}

\subsection{Latar Belakang}

Bagi masyarakat di desa beternak itik menjadi sebuah keharusan dan telah menyatu dengan kehidupan sehari-hari.Beternak itik bagi masyarakat merupakan kegiatan sampingan dalam upaya meningkatkan pendapatan keluarga. Masyarakat lebih tertarik memelihara itik dikarenakan ternak itik relatif tahan terhadap penyakit dibandingkan dengan unggas lainnya, oleh karena itu usaha ternak itik memiliki resiko yang relatif lebih kecil dan cara pemeliharan itik juga cukup sederhana.

Di Indonesia ternak itik merupakan salah satu komoditas peternakan yang mempunyai nilai ekonomis dan potensi yang cukup tinggi, baik sebagai sumber protein hewani maupun sebagai sumber tambahan dalam menunjang kehidupan keluarga (Rasyaf, 2000).Masyarakat memelihara itik disamping untuk mendapatkan hasil berupa telur juga sebagai penghasil daging.Ternak itik merupakan ternak unggas penghasil daging yang cukup potensial.Daging itik merupakan sumber protein yang bermutu tinggi, karena itu pengembangannya diarahkan kepada produksi daging yang banyak dan cepat sehingga mampu memenuhi permintaan konsumen. Salah satu itik yang sangat potensial dikembangkan sebagai itik pedaging adalah itik peking.

Kontribusi itik dalam penyediaan daging nasional masih rendah, yakni sebesar 0,94\%. Produksi daging itik mengalami peningkatan setiap tahunnya, sehingga diharapkan kontribusi daging unggas ini terhadap penyediaan protein hewani semakin meningkat (Dirjen Peternakan, 2013).
Kandungan gizi yang terdapat pada daging itik cukup tinggi, antara lain kandungan protein $21,4 \%$, lemak $8.2 \%$, abu $1.2 \%$ dan nilai energi (per 100 gr kkal) $159 \mathrm{kkal} / \mathrm{kg} \quad$ (Srigandono, 1996).Selanjutnya dijelaskan bahwa tujuan utama beternak itik pedaging adalah untuk dapat meningkatkan pertambahan bobot badan secara cepat, ekonomis dan menghasilkan daging yang memiliki gizi tinggi untuk memenuhi permintaan masyarakat. ltik merupakan sumber daging nomor dua setelah ayam baik ayam kampung maupun ayam broiler.Sedangkan kunci sukses memelihara itik pedaging terletak pada jumlah dan cara pemberian pakan.

Pakan yang diberikan harus bergizi tinggi untuk mendukung pertumbuhan.Selain kandungan gizi kualitas pakan yang diberikan juga harus baik (Ranto dan Maloedin, 2005).Dalam memberikan pakan itik biasanya peternak memberikan pakan tersebut dengan terlebih dahulu mencampurnya dengan air.Cara ini dilakukan agar itik lebih mudah mengambil dan menelannya.Jumlah air yang dicampurkan tidak diukur dengan pasti tapi hanya berdasarkan keinginan atau kebiasaan peternak saja.Itik kurang dapat beradaptasi dengan pakan kering, sehingga pakan yang diberikan harus basah, dengan kadar air maksimum 20\% (Ranto dan Maloedin, 2005).

Apakah pencampuran pakan dengan air akan mempengaruhi performa itik belum diketahui secara pasti. Untuk mengetahui pengaruh penambahan air dalam pakan itik terhadap performans itik pedaging khususnya itik peking jantan masa starter maka perlu dilakukan penelitian. 


\subsection{Identifikasi Masalah}

Apakah terdapat pengaruh dari pemberian pakan dengan persentase penambahan air yang berbeda terhadap performans itik peking jantan fase starter.

\subsection{Tujuan Penelitian}

Untuk mengetahui performa itik pekingjantan pada fase starter yang diberikan pakan dengan persentase pertambahan jumlah air yang berbeda.

\subsection{Hipotesis}

Pemberian pakan dengan persentase penambahan air yang berbeda berpengaruh terhadap performans itik peking jantan pada fase starter.

\section{METODE PENELITIAN}

\subsection{Waktu dan Tempat Penelitian}

Penelitian akan dilaksanakan di Desa Garot Cut Kecamatan Indrajaya Kabupaten Pidie yang dimulai pada tanggal 1 sampai dengan 31 Agustus 2015.

\subsection{Materi Penelitian}

Materi yang digunakan dalam penelitian ini terdiri dari 60 ekor anak itik peking jantan yang berumur satu minggu (DOD). Anak itik dibeli di Poultry ShopKota Sigli.

Alat-alat yang digunakan dalam penelitian ini terdiri dari tempat pakan, tempat minum,lampu,timbangan,sedang pakan yang diberikan adalah ransum standar komersial (511) PT. Charoen Pokphand Indonesia.

\subsection{Prosedur Penelitian}

Kandang dipersiapkan dua minggu sebelum pelaksanaan penelitian. Kandang dibuat dengan menggunakan bambu berbentuk boks dengan ukuran masing-masing boks 50 x $50 \mathrm{~cm}$. Seminggu sebelum kandang digunakan untuk penelitian terlebih dahulu dibersihkan dan disuci hamakan dengan menggunakan desinfektan (rodalon) agar kandang bersih dan bebas dari kuman dan bakteri.

Anak itik ditempatkan dalam masing-masing boks sejumlah 3 ekor. Setiap boks dilengkapi dengan satu tempat pakan dan satu tempat minum. Lampu pijar dengan kapasitas 60 watt ditempatkan ditengahtengah setiap 4 boks hal ini untuk menghangatkat anak itik pada malam hari dandisiang hari ketika cuaca mendung atau hujan.

Pakan dan air diberikan secara ad libitum, perlakuan pemberian pakan terlebih dahulu dilakukan dengan mencampurkan air sesuai dengan perlakuan.Sebelum pakan diberikan terlebih dahulu ditimbang dan dicatat kemudian sisa pakan setiap harinya juga ditimbang dan dicatat, hal ini untuk mengetahui berapa konsumsi pakan setiap harinya.

Pada saat awal dimulainya penelitian semua anak itik ditimbang dan dicatat, ini dilakukan untuk mengetahui berat awal dari anak itik.Kemudian setiap akhir periode anak itik juga ditimbang dan dicatat beratnya.

\subsection{Variable yang Diamati}

Adapun variable yang diamati adalah:

1. Konsumsi Ransum

Konsumsi pakan dihitung berdasarkan jumIah pakan yang diberikan dikurangi dengan sisa pakan (gram/ekor/minggu).

2. Pertambahan Bobot Badan

Pertambahan bobot badan diukur berdasarkan bobot badan akhir dikurangi dengan bobot badan awaI dari setiap periode pengamatan.

3. Konversi Ransum

Konversiransum dihitung dengan membandingkan jumlah ransum yang dikonsumsi dengan pertambahan bobot badan (gram/ekor/ minggu).

\subsection{Rancangan Penelitian}

Penelitian dilakukan dengan menggunakanRancangan Acak Lengkap (RAL) yang terdiri dari 4 perlakuan dengan 5 ulangan.Data yang diperoleh dianalisis sidik ragam dengan model matematik sbb:

$$
\begin{aligned}
& \text { Yij }=\mu+\tau i+\varepsilon i j \\
& (i=1,2,3, \ldots . . p ; j=1,2,3, \ldots \ldots u 1)
\end{aligned}
$$

Keterangan:

$\mathrm{Y}_{\mathrm{ij}}=$ Nilai pengamatan pada perlakuan ke-i dan ulangan ke-j

$\mu \quad=$ Rata-rata umum

$\tau \mathrm{i}=$ Perlakuan ke-i

iij = Kesalahan (galat) percobaan pada perlakuan ke-i dan ulangan ke-j

Jika terdapat pengaruh nyata atau sangat nyata maka dilanjutkan dengan uji BNT $(0,05)$.

Adapun perlakuan dari penelitian ini adalah:

1. $\mathrm{A}=$ Ransum komersial $511+0 \%$ air sebagai kontrol

2. $\mathrm{B}=$ Ransum komersial + penambahan $10 \%$ air dari berat ransum

3. $\mathrm{C}=$ Ransum komersial + penambahan $20 \%$ air dari berat ransum

4. $\mathrm{D}=$ Ransum komersial + penambahan $30 \%$ air dari berat ransum

\section{HASIL DAN PEMBAHASAN}

\subsection{Konsumsi Ransum}

Rata-rata jumlah konsumsi ransum itik peking per minggu selama empat minggu masa penelitian disajikan pada Gambar 1 di bawah.Sedangkan konsumsi ransum disajikan pada Gambar 2.

Hasil analissi ragam menunjukkan bahwa akibat dari penambahan air dengan persentase yang berbeda di dalam ransum berpengaruh sangat nyata terhadap konsumsi ransum itik peking jantan 
perminggu maupun selama empat minggu masapenelitian.

Gambar 1.

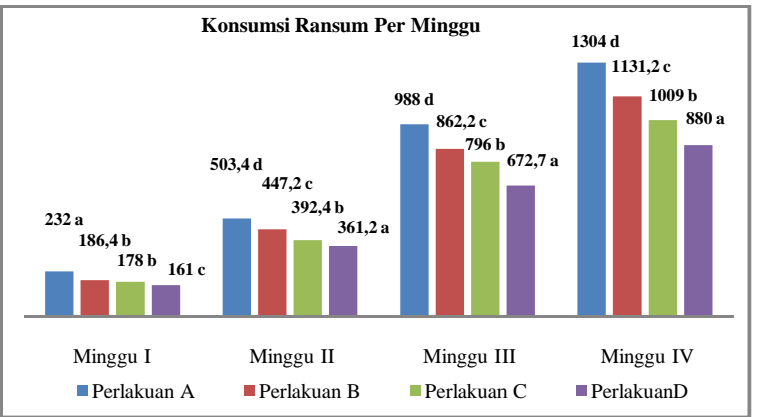

Keterangan: Angka yang diikuti oleh huruf yang sama pada kolom yang sama berbeda sangat nyata nyata pada taraf $\alpha=5 \%$ (uji (BNT)

Gambar 2.

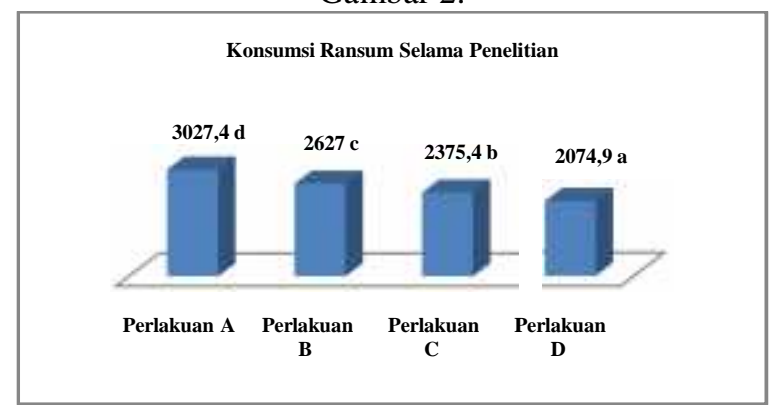

Keterangan: Angka yang diikuti oleh huruf yang sama pada kolom yang sama berbeda sangat nyata nyata pada taraf $\alpha=5 \%$ (uji $(\mathrm{BNT})$

Gambar 1 dan Gambar 2 diatas, memperlihatkan bahwa semakin tingginya persentase penambahan air di dalam ransum, tingkat konsumsi ransum semakin rendah. Konsumsi ransum itik pada Minggu I sampai Minggu ke IV tertinggi dijumpai pada perlakuan A (penambahan 0\% air), sedangkan konsumsi ransum terendah diperoleh pada perlakuan D (penambahan 30\% air).Hasil uji BNT menunjukkan bahwa antar perlakuan menunjukkan perbedaan yang sangat nyata.

Rendahnya konsumsi ransum seiring tingginya persentase penambahan air diduga disebabkan anak itik lebih cepat merasa kenyang ataupun dapat merubah warna, rasa maupun bau ransum sehingga palatabilitas ransum menjadi menurun.Rendahnya konsumsi ransum seiring tingginya persentase penambahan air diduga disebabkan anak itik lebih cepat merasa kenyang ataupun dapat merubah warna, rasa maupun bau ransum sehingga palatabilitas ransum menjadi menurun.Hal ini sesuai dengan pendapat Wahyu (1992) bahwa konsumsi pakan unggas dipengaruhiolehbanyak faktor yaitu jenisunggas, temperature lingkungan,bobot badan, jenis kelamin, umur, tingkat produksi telur, ukuran telur, bulu penutup, aktivitas ternak, tipe kandang, palata bilitas pakan, kandungan energy pakan, kualitas nutrisi pakan, konsumsi air serta kandungan lemak tubuh dan tingkat cekaman.

\subsection{Pertambahan Bobot Badan Itik}

Data mengenai rata-rata pertambahan bobot badan itik per ekor/minggu selama empat minggu masa penelitian dapat dilihat pada Gambar 3 di bawah.Sedangkan rata-rata pertambahan bobot badan itik selama penelitian disajikan pada Gambar 4.

Hasil analissi ragam menunjukkan bahwa akibat dari penambahan air dengan persentase yang berbeda di dalam ransum tidak berpengaruh nyata terhadap pertambahan bobot badan itik peking jantan per minggu maupun selama empat minggu masa penelitian

Gambar 3.

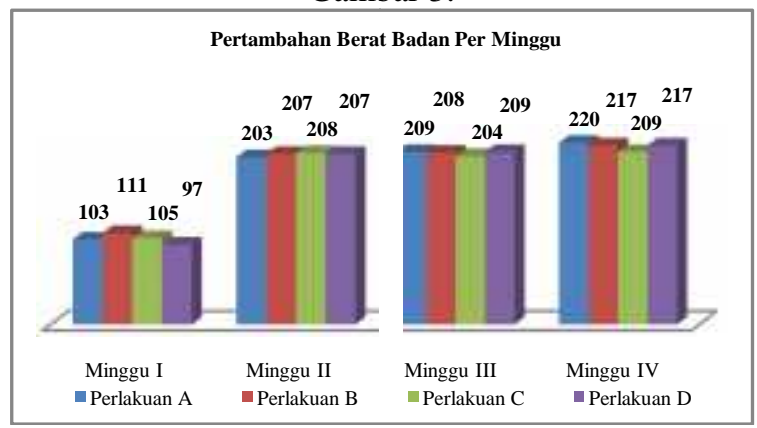

Gambar 4.

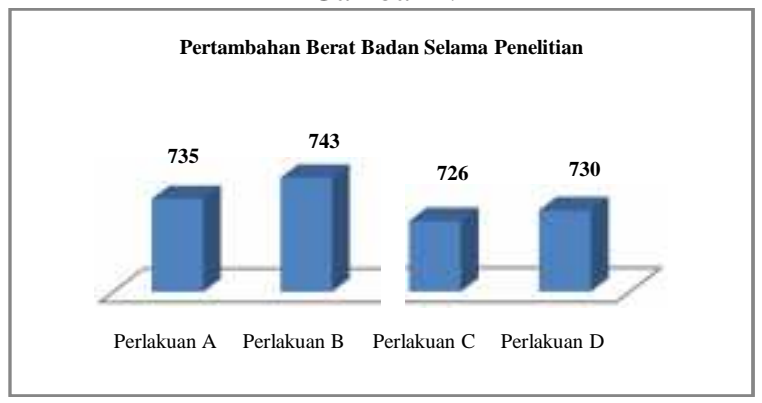

Dari Gambar 4 diatas, terlihat bahwa pertambahan bobot badan itik peking jantan tertinggi dijumpai pada perlakuan B yaitu penambahan $10 \%$ air dengan total pertambahan bobot badan sebesar 743 gr, sedangkan pertambahan bobot badan terendah dijumpai pada perlakuan $\mathrm{C}$ (penambahan $30 \%$ air) yaitu sebesar 726 gr, namun tidak terdapat perbedaan yang nyata antar semua perlakuan.

Tingkat konsumsi ransum antar perlakuan menunjukkan perbedaan yang sangat nyata (Gambar 2) namun pertambahan bobot badan akibat dari perlakuan perbedaan persentase penambahan air dalam ransum tidak memperlihatkan pengaruh yang nyata.Zhang et al. (2007) menjelaskan bahwa masukan pakan yang berlebihan pada unggas air mempengaruhi daya cerna nutrisi, penyerapan dan pemanfaatannya. Wen et al. (2015) mengemukakan 
bahwa konsumsi pakan yang berlebih tidak bisa meningkatkan bobot badan lebih tinggi akan tetapi akan membuat daya cerna nutrisi menjadi menurun dikarenakan itik pekin kekenyangan.

\subsection{Konversi Ransum}

Data rata-rata konversi ransum itik peking jantan per minggu selama empat minggu masa penelitian dapat dilihat pada Gambar 5 di bawah. Sedangkan rata-rata konversi ransum itik disajikan pada Gambar 6. Hasil analissi ragam menunjukkan bahwa akibat dari penambahan air dengan persentase yang berbeda di dalam ransum berpengaruh sangat nyata terhadap konversi ransum itik peking jantan per minggu maupun selama empat minggu masa penelitian.

\section{Gambar 5}

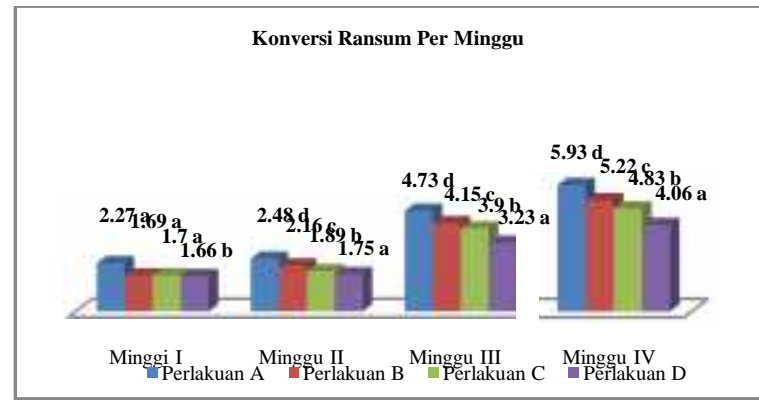

Keterangan: Angka yang diikuti oleh huruf yang sama pada kolom yang sama berbeda tidak nyata pada taraf $\alpha=5 \%$ (uji (BNT)

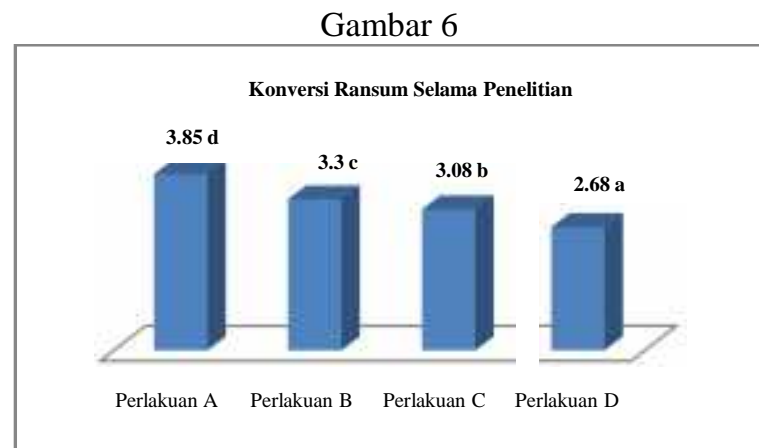

Keterangan: Angka yang diikuti oleh huruf yang sama pada kolom yang sama berbeda tidak nyata pada taraf $\alpha=5 \%$ (uji (BNT)

Gambar 5 dan 6 diatas, memperlihatkan bahwa semakin tingginya persentase penambahan air di dalam ransum tingkat konversi ransumnya semakin rendah (semakin baik), artinya satuan bobot badan yang dihasilkan semakin tinggi.

Konversi ransum itik peking jantan pada Minggu I sampai dengan Minggu ke IV terendah dijumpai pada perlakuan D (penambahan $30 \%$ air) yaitu masing-masing sebesar 1,66; 1,75; 3,23 dan 4,06. Data tersebut juga memperlihatkan bahwa konversi ransum itik peking jantan setiap minggu semakin tinggi, artinya kemampuan itik mengkonversikan ransum semakin berkurang.
Konversi ransum selama empat minggu masa penelitian, yang terendah dijumpai pada Perlakuan D (penambahan $30 \%$ air) yaitu 2,68. Sedangkan konversi ransum yang tertinggi dijumpai pada Perlakuan A (penambahan 0\% air) yaitu sebesar 3,85. Hasil uji BNT menunjukkan bahwa antar perlakuan berbeda sangat nyata. Wen et al. (2015) mengemukakan bahwa konsumsi pakan yang berlebih tidak bisa meningkatkan bobot badan lebih tinggi akan tetapi akan membuat daya cerna nutrisi menjadi menurun dikarenakan itik pekin kekenyangan. Puvanendran et al. (2003) mengemukakan bahwa umumnya, tingkat konsumsi pakan yang tinggi mengarah ke tingginya bagian dari bahan makanan yang melalui saluran pencernaan, daya cerna rendah dan rendahnya penyerapan nutrisi. Dengan rendahnya daya cerna dan penyerapan nutrisi maka konversi pakan nilainya akan lebih tinggi. Hal ini sejalan dengan hail penelitian yaitu terlihat bahwa konsumsi pakan lebih tinggi jika ransum tidak ditambahkan air dan antar perlakuan berbeda sangat nyata. Sedangkan konversi pakan yang lebih baik jika ransum ditambahkan air sampai dengan 30\% dari berat ransum dan berbeda sangat nyata antar perlakuan, sementara pertambahan bobot badan tidak berpengaruh nyata.

\section{KESIMPULAN DAN SARAN \\ 4.1. Kesimpulan}

- Persentase penambahan jumlah air dalam ransum komersial berpengaruh sangat nyata terhadap konsumsi ransum dan konversiransum itik peking jantan pada preriode starter namun tidak berpengarh nyata terhadap pertambahan bobot badan.

- Perlakuan penambahan air sebesar 30\% dari berat ransum menghasilkan konsumsi ransum dan konversi ransum terendah sedangkan konsumsi ransumdan konversi ransum tertinggi dengan perlakuan tanpa penambahan air. Antar semua perlakuan berbeda sangat nyata.

\subsection{Saran}

- Pemeliharan itik pekingjantan pada periode starter disarankan menggunakan pakan dengan pencampuran $30 \%$ air.

- Perlu dilakukan penelitian lebih lanjut untuk mengetahui pengaruh persentase penambahan air dalam ransum terhadap performa itik pekingjantan pada periode selanjutnya.

\section{DAFTAR PUSTAKA}

Kartasudjana, R. 2002. Manajemen Ternak Unggas. Fakultas Peternakan. Universitas Padjajara. Bandung.

Pawlik, J. R., A. I. Fengler, and R. R. Marquardt, 1990.Improvement of the nutritional value of rye by the partialhydrolysis of the 
viscous water soluble pentosans follow-ing water-soaking or fungal enzyme treatment. Br. Poult.Sci. 31:525-538.

Puvanendran V, Boyce DL, Brown J. 2003. Food rationrequirements of $0+$ yellowtail flounder Limanda ferruginea(Storer) juveniles. Aquaculture. 220:459-475.

Ranto dan Maloedyn, S. 2007. Panduan Lengkap Beternak Itik Edisi Revisi. PT Agromedia Pustaka. Jakarta.

Rasyaf, M. 2000. Memasarkan Hasil Peternakan. Penebar Swadaya. Jakarta.

Srigandono, B. 1996.Beternak ltik Pedaging. Tribus Agriwudya. Ungaran.

Steel, R.G.D., and J.H. Torries. 1981. Principles and Procedures of Statistic. 2 th Ed. Mc. GrawHill International Book Company. Tokyo Japan.Wahyu. 1992. Ilmu Nutrisi Ternak Unggas. Gadjah Mada University Press.Yogyakarta.

Zhang CL, Hou SS, Wang YH, Liu ZY, Xie M. (2007). Feedinput and excreta collection time in metabolisable energyassays for ducks. Czech J Anim Sci. 52:463-468.

Zhi-Guo Wen, Ming Xie, Ahmed-Mohamed Fouad, Jing Tang, Uzma Maqbool, Wei Huang dan Shui-Sheng Hou (2015). The effect of feed consumption levels on growth performance and apparent digestibility of nutrients in White Pekin ducks.Journal of Applied Animal Research. 43:1. 112-117. 